infection, United States. Emerg Infect Dis. 2014;20:872-4. http://dx.doi.org/10.3201/eid2005.131628

4. Bevins SN, Pedersen K, Lutman MW, Gidlewski T, Deliberto TJ. Consequences associated with the recent range expansion of nonnative feral swine. Bioscience. 2014;64:291-9. http://dx.doi.org/ 10.1093/biosci/biu015

5. Glazier N. Brucellosis-USA: (New York) swine, human, 2016. ProMED mail. 2017 Mar 17 [cited 2077 Dec 2]. http://www.pro-medmail.org, archive no. 20170321.4912122.

6. Lee DU, Kwon T, Je SH, Yoo SJ, Seo SW, Sunwoo SY, et al. Wild boars harboring porcine epidemic diarrhea virus (PEDV) may play an important role as a PEDV reservoir. Vet Microbiol. 2016;192:90-4. http://dx.doi.org/10.1016/j.vetmic.2016.07.003

7. Bowman AS, Krogwold RA, Price T, Davis M, Moeller SJ. Investigating the introduction of porcine epidemic diarrhea virus into an Ohio swine operation. BMC Vet Res. 2015;11:38. http://dx.doi.org/10.1186/s12917-015-0348-2

8. Scott A, McCluskey B, Brown-Reid M, Grear D, Pitcher P, Ramos G, et al. Porcine epidemic diarrhea virus introduction into the United States: root cause investigation. Prev Vet Med. 2016;123:192-201. http://dx.doi.org/10.1016/ j.prevetmed.2015.11.013

9. Kim Y, Yang M, Goyal SM, Cheeran MC-J, Torremorell M. Evaluation of biosecurity measures to prevent indirect transmission of porcine epidemic diarrhea virus. BMC Vet Res. 2017;13:89. http://dx.doi.org/10.1186/s12917-017-1017-4

Address for correspondence: Sarah N. Bevins, USDA National Wildlife Research Center, 4101 Laporte Ave, Fort Collins, CO 80521, USA; email: sarah.n.bevins@aphis.usda.gov

\title{
LETTERS
}

\section{Adenovirus Type 4 Respiratory Infections among Civilian Adults, Northeastern United States, 2011-2015}

\section{Breda L. Lynch, Jonathan Dean, Deirdre Brady, Cillian De Gascun}

\author{
Author affiliations: Mater Misericordiae University Hospital, \\ Dublin, Ireland (B.L. Lynch, D. Brady); National Virus Reference \\ Laboratory, Dublin (J. Dean, C. De Gascun) \\ DOI: https://doi.org/10.3201/eid2407.180137
}

To the Editor: We read with interest the article by Kajon et al. (1), which highlighted that human adenovirus type 4 might be an underrecognized cause of acute respiratory disease (ARD) outside military settings. We report that human adenovirus B7 (HAdV-B7) might also be a cause of this disease.

HAdV-B7 is well recognized as a causative agent of neonatal disease and infections in immunocompromised patients. However, we identified an unusual cluster of 4 cases of severe ARD caused by this pathogen in immunocompetent adults in Dublin, Ireland. These patients had acute respiratory illness when they came to the emergency department of Mater Misericordiae University Hospital in Dublin. The patients came to the hospital over a 4-week period during the summer of 2017, and each patient required intensive care support for single-organ failure. Three patients required intubation and ventilation; all 4 patients recovered.
Three patients reported gastrointestinal and respiratory symptoms, as seen in Oregon, USA (2). Although coinfection with other viruses or bacteria has been described (3), only 1 patient in our cluster had a possible concomitant pathogen. None of the 4 patients were given antiviral therapy but all received antimicrobial drugs.

All 4 case-patients were either homeless or in temporary accommodations for homeless adults, but we did not identify any epidemiologic link. The Department of Public Health and temporary accommodation sites were notified to raise awareness and offer early testing of symptomatic persons. However, no additional cases were identified.

HAdV-B7 was identified by BLAST analysis (https:// blast.ncbi.nlm.nih.gov/Blast.cgi) of viral hexon genes (4). Each virus had $100 \%$ identity within the region sequenced to a strain previously associated with respiratory illness in a military training camp in China (GenBank accession no. KP896481).

This cluster of HAdV-B7 causing severe ARD in immunocompetent adults appears to have no clear epidemiologic link. We agree that HAdV might be an underrecognized pathogen in severe communityonset ARD. Testing for viral respiratory pathogens should be considered in all patients and not just the immunocompromised.

\section{References}

1. Kajon AE, Lamson DM, Bair CR, Lu X, Landry ML, Menegus M, et al. Adenovirus type 4 respiratory infections among civilian adults, northeastern United States, 2011-2015. Emerg Infect Dis. 2018;24:201-9. http://dx.doi.org/10.3201/eid2402.171407

2. Scott MK, Chommanard C, Lu X, Appelgate D, Grenz L, Schneider E, et al. Human adenovirus associated with severe 
respiratory infection, Oregon, USA, 2013-2014. Emerg Infect Dis. 2016;22:1044-51. http://dx.doi.org/10.3201/eid2206.151898

3. Berciaud S, Rayne F, Kassab S, Jubert C, Faure-Della Corte M, Salin F, et al.; Typadeno Study Members. Adenovirus infections in Bordeaux University Hospital 2008-2010: clinical and virological features. J Clin Virol. 2012;54:302-7. http://dx.doi.org/10.1016/ j.jcv.2012.04.009

4. Casas I, Avellon A, Mosquera M, Jabado O, Echevarria JE, Campos RH, et al. Molecular identification of adenoviruses in clinical samples by analyzing a partial hexon genomic region. J Clin Microbiol. 2005;43:6176-82. http://dx.doi.org/10.1128/ JCM.43.12.6176-6182.2005

Address for correspondence: Breda L. Lynch, Department of Clinical Microbiology, Mater Misericordiae University Hospital, Eccles St, Dublin 7, Ireland; email: bredalouiselynch@gmail.com

\section{Novel Highly Pathogenic Avian Influenza A(H5N6) Viruses in the Netherlands}

\author{
Yifei Xu \\ Author affiliation: University of Oxford, Oxford, UK \\ DOI: https://doi.org/10.3201/eid2407.180635
}

To the Editor: In their recent article, Beerens et al. (1) reported detection of a novel clade 2.3.4.4 group B highly pathogenic avian influenza (HPAI) H5N6 subtype virus in wild birds and poultry in the Netherlands in December 2017. This novel virus is a reassortant of the HPAI H5N8 subtype virus with polymerase basic 2 (PB2) and neuraminidase genes from the Eurasian gene pool. This study highlighted concerns over the recent emergence and spread of these viruses. H5N6 subtype viruses have been identified in multiple Eurasian regions and have shown diverse genotypes since the beginning of 2017. Clade 2.3.4.4 group B H5N6 subtype viruses were reported to have affected migratory birds and poultry in South Korea in December 2017 (2). The viruses from South Korea have PB2 and polymerase acidic genes distinct from those of viruses from the
Netherlands. H5N6 subtype viruses were also detected in Greece, Japan, and Taiwan in 2017. Viruses from these regions have the same genotype, but PB2, polymerase acidic, and neuraminidase genes differ from those in the viruses from the Netherlands.

Clade 2.3.4.4 group A H5N8 subtype viruses emerged in East Asia in early 2014 and subsequently spread, along migratory bird routes, to Europe and North America by the end of 2014. H5N8 subtype and reassortant viruses, including $\mathrm{H} 5 \mathrm{~N} 1$ and $\mathrm{H} 5 \mathrm{~N} 2$ subtypes (3), resulted in the deaths of 7.5 million turkeys and 42.1 million chickens in the United States alone. Since June 2016, these H5N8 subtype viruses have circulated in Europe and reassorted with local low pathogenicity avian influenza viruses. Group B H5N8 subtype viruses caused the long-lasting second wave of outbreaks in wild birds and poultry in 30 countries in Europe, including the Netherlands, Belgium, Luxembourg, and the United Kingdom (4). It is hard to predict whether novel clade 2.3.4.4 group B H5N6 subtype viruses might trigger a similar new wave of massive HPAI H5Nx outbreaks in wild and domestic birds and even cause infections among poultry workers. However, more surveillance data are needed to investigate the genetic diversity and evolution of these viruses and how widely they are circulating in wild birds.

\section{References}

1. Beerens N, Koch G, Heutink R, Harders F, Vries DP, Ho $\mathrm{C}$, et al. Novel highly pathogenic avian influenza A(H5N6) virus in the Netherlands, December 2017. Emerg Infect Dis. 2018;24:770-3. http://dx.doi.org/10.3201/eid2404.172124

2. Kim Y-I, Si Y-J, Kwon H-I, Kim E-H, Park S-J, Robles NJ, et al. Pathogenicity and genetic characterisation of a novel reassortant, highly pathogenic avian influenza (HPAI) H5N6 virus isolated in Korea, 2017. Euro Surveill. 2018;23: doi: 10.2807/1560-7917. ES.2018.23.7.18-00045. http://dx.doi.org/10.2807/1560-7917. ES.2018.23.7.18-00045

3. Lee D-H, Bahl J, Torchetti MK, Killian ML, Ip HS, DeLiberto TJ, et al. Highly pathogenic avian influenza viruses and generation of novel reassortants, United States, 2014-2015. Emerg Infect Dis. 2016;22:1283-5. http://dx.doi.org/10.3201/eid2207.160048

4. Poen MJ, Bestebroer TM, Vuong O, Scheuer RD, van der Jeugd HP, Kleyheeg E, et al. Local amplification of highly pathogenic avian influenza H5N8 viruses in wild birds in the Netherlands, 2016 to 2017. Euro Surveill. 2018;23:23. http://dx.doi.org/10.2807/1560-7917.ES.2018.23.4.17-00449

Address for correspondence: Yifei Xu, University of Oxford, Nuffield Department of Medicine, John Radcliffe Hospital, Oxford OX3 9DU, UK; email: yifei.xu@ndm.ox.ac.uk 